\title{
Real-time laboratory surveillance of sexually- transmissible infections in Marseille university hospitals reveals rise of gonorrhoea, syphilis and human immunodeficiency virus seroconversions in 2012
}

P Colson 1,2,3 F Gouriet $^{1,2,3}$, S Badiaga ${ }^{2,4}$, C Tamalet $^{1,2}$, A Stein2,5, D Raoult (didier.raoult@gmail.com) ${ }^{1,2}$

1. Pôle des Maladies Infectieuses et Tropicales Clinique et Biologique, Fédération de Bactériologie-Hygiène-Virologie, University Hospital Centre Timone, Institut Hospitalo-Universitaire (IHU) Méditerranée Infection, Assistance Publique - Hôpitaux de Marseille, Marseille, France

2. Aix-Marseille University, Unité de Recherche sur les Maladies Infectieuses et Tropicales Emergentes (URMITE; Research Unit on Infectious and Tropical Emerging Diseases) UM 63 CNRS 7278 IRD 198 INSERM U1095, Faculties of Medicine and Pharmacy, Marseille, France

3. These authors contributed equally to the work

4. Service d'Accueil des Urgences, (Accident and Emergency Department), Assistance Publique des Hôpitaux de Marseille, Hôpital Nord, Marseille, France

5. Pôle des Maladies Infectieuses et Tropicales Clinique et Biologique, Service de Maladies Infectieuses, Institut HospitaloUniversitaire (IHU) Méditerranée Infection, Hôpital Conception, Assistance Publique - Hôpitaux de Marseille, Marseille, France

Colson P, Gouriet F, Badiaga S, Tamalet C, Stein A, Raoult D. Real-time laboratory surveillance of sexually-transmissible infections in Marseille University hospitals reveals rise of gonorrhoea, syphilis and human immunodeficiency virus seroconversions in 2012 . Euro Surveill. 2013;18(7):pii=20402. Available online: http://

www.eurosurveillance.org/ViewArticle.aspx?Articleld=20402

Real-time systematic monitoring of the number of infections diagnosed in our clinical microbiology laboratory in Marseille recently drew attention to the fact that the incidence of gonorrhoea was 10 -fold greater from September through December 2012 than during same months of previous years. We also found an increase in the annual incidence of syphilis and human immunodeficiency virus seroconversion. Our system allowed timely identification of an increase in sexually-transmitted infections in Marseille for the whole year of 2012 .

Routine laboratory surveillance in Marseille, France identified a rise in the number of diagnosed gonococcal infections in the last quarter of 2012. We therefore analysed the annual incidence data of sexually transmitted infections (STI) and noted an increase not only in the incidence of gonorrhoea but also of syphilis and human immunodeficiency virus (HIV) infections.

\section{Laboratory surveillance in Marseille}

Systematic monitoring of the number of infections diagnosed through tests performed by the laboratories is a new monitoring mode to detect seasonality and variations in the incidence of infectious and contagious diseases [1]. We have since 2002 been using such a system in our clinical microbiology laboratory [2], which is the sole laboratory for Marseille University hospitals and performs annually for the diagnosis of infections approximately 145,000 serological tests, 200,000 PCR tests, as well as cultures of bacteria, yeasts or viruses from 220,000 samples. Our computer tool gives a signal when the weekly incidence of a given disease is greater than the mean plus two standard deviations [2].

Marseille is the second largest city in France with about 850,000 inhabitants in the city itself and $1,560,000$ inhabitants in the entire Marseille urban unit $(2.5 \%$ of the metropolitan population in France). The annual activity of Marseille University hospitals includes about 890,000 consultations, 125,000 admissions, 151,000 persons seen in emergency wards, and 112,000 hospitalised patients. No data on the recent incidence or prevalence of diagnosed STI are available for other laboratories that cover our geographical area, nor, to our best knowledge, are any national data.

\section{Increase in diagnosed sexually transmitted infections}

Seven cases of gonorrhoea were diagnosed in September 2012, whereas the mean number was 1.2 cases (range: 0-3 cases) from January 2005 through August 2012 (Figure, panel A), which prompted us to investigate the data from our surveillance system for other STIs. This analysis confirmed that there was an increase in the annual incidence of serologically diagnosed active syphilis, which was 2.7 -fold higher in 2012 (164 cases) compared to the period from 2005 to 2011, during which it ranged from 44 to 84 (mean: 62 cases) (Figure, panel B). Concurrently, the annual number of HIV seroconversion was 1.8-fold higher in 2012 (16 cases) than during the period from 2005 to 2011 (mean: 9 cases) (Figure, panel C). In addition, we confirmed a 10 -fold increase in the number of gonorrhoea cases diagnosed from September to December 2012 
compared with the same months of the seven previous years. Regarding Chlamydia trachomatis infections, we have not noticed any significant increase in numbers, but our monitoring for this particular pathogen only started in January 2011.

There have not been any recent changes in testing procedures for STI in our laboratory.

We looked at the sex and age of all patients who experienced gonorrhoea, active syphilis or HIV

\section{FIGURE}

Culture isolation of Neisseria gonorrhoeae (A), serology indicating active syphilis (B) and primary infection with human immunodeficiency virus (C), Marseille, 2005-2012
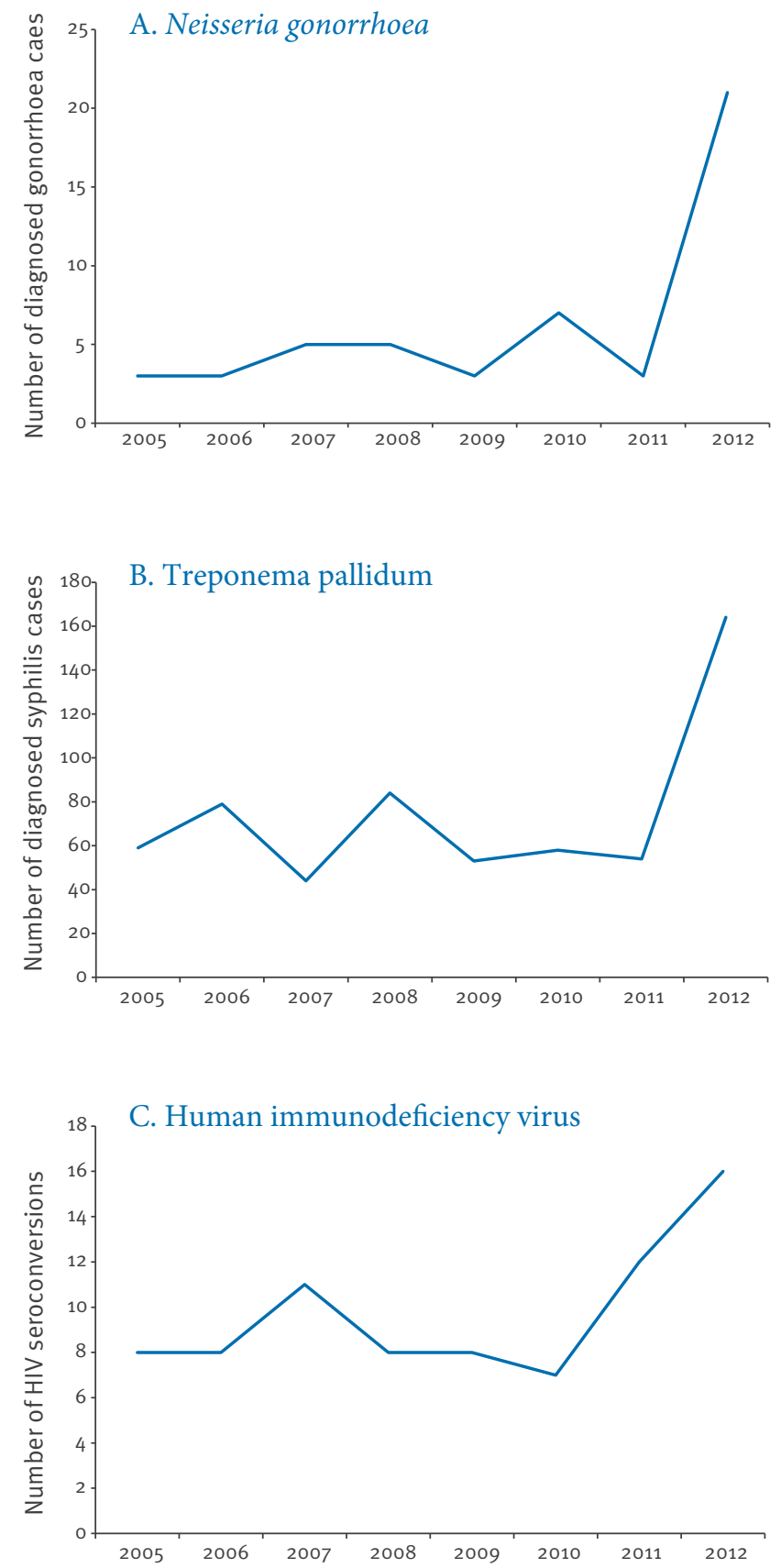

HIV: human immunodeficiency virus. seroconversion. It was found that they were mostly young men. Indeed, in 2012, 38 of 47 gonorrhoea cases were diagnosed in men whose mean age ( \pm standard deviation) was $29 \pm 10$ years (range: $16-51$ years); $89 \%$ of syphilis were diagnosed in men whose mean age was 46 \pm 14 years (range: $21-87$ years); and all 16 cases diagnosed with HIV seroconversion were men whose mean age was $39 \pm 15$ years (range: $21-72$ years) and among whom 6 of 16 were younger than 30 years. Among persons who experienced HIV seroconversion, we found a significant rise of the male/female sex ratio in the period from 2005 to 2010 (37 men among 50 cases) and the period 2011 and 2012 (27 men among 28 cases) ( $p=0.014)$, and a 2.2-fold rise of the annual number of men having sex with men who experienced HIV seroconversion in the period from 2005 to 2010 (31 cases) and the period 2011 and 2012 (23 cases).

\section{Trends in other countries}

Interestingly, other countries in Europe also described recent increases in the incidence of several STIs, for instance in England, Germany and Sweden, particularly among MSM [3]. In France, a 52\% increase in gonorrhoea was described between 2008 and 2009 [4], but not in the following years. In Europe, a rise of gonorrhoea notifications has been reported in several countries [3]. In England, the increase was $25 \%$ in the general population, and as high as $61 \%$ among men who have sex with men among whom $42 \%$ of diagnoses were in those aged 25-34 years [5]. The number of syphilis cases in France nationally declined in 2008 and 2009 after an earlier increase in 2007 [6], which is in contrast to our data for Marseille. In England, a $10 \%$ increase in syphilis was noted in 2011, reaching $28 \%$ among young men who have sex with men [5]. In Germany, syphilis cases rose by $22 \%$ in 2011 , mainly in men [7]. Finally, regarding HIV, a significant increase of the number of positive serology results was reported in some regions of metropolitan France between 2007 and 2011 [8]. The estimated yearly HIV incidence among MSM was $3.8 \%$ person-years in France in 2009 and $2.5 \%$ in Europe, North America and Australia for the period 1995-2005 [9,10].

In conclusion, our monitoring system based on laboratory diagnoses, which mimics the system implemented in England and Wales can detect early changes in the incidence of STIs. Such real-time systematic laboratory surveillance of infectious diseases is critical for an accurate appreciation of incidence and for appropriate prevention and treatment, and is currently lacking in France. In addition, among the STIs analysed here, notification is only mandatory for HIV infection. Finally, our system is unique in that it can pick up signals in real time, which allowed analysis of the full 2012 data already in January 2013 and led to the identification of the increasing trend in STIs in Marseille.

Acknowledgements

We are grateful to Dr Hervé Chaudet for his helpful comments. 
No funding and potential competing interests for all authors.

\section{Authors' contributions}

DR, FG and PC conceived the study and wrote the manuscript. DR, PC, FG, SB, CT and/or AS provided and analysed the data.

\section{References}

1. Enki DG, Noufaily A, Garthwaite PH, Andrews NJ, Charlett A Lane C, et al. Automated biosurveillance data from England and Wales, 1991-2011. Emerg Infect Dis. 2013;19(1):35-42. http://dx.doi.org/10.3201/eid1901.120493 PMid:23260848 PMCid:3557985

2. Parola P, Colson P, Dubourg G, Million M, Charrel R, Minodier $P$, et al. Letter to the editor. Group A streptococcal infections during the seasonal influenza outbreak 2010/11 in South East England. Euro Surveill. 2011;16(11):pii=19816. Available from: http://www.eurosurveillance.org/ViewArticle. aspx?Articleld=19816

3. Van de Laar M, Spiteri G. Increasing trends of gonorrhoea and syphilis and the threat of drug-resistant gonorrhoea in Europe. Euro Surveill 2012;17(29):pii=20225. Available from: http:// www.eurosurveillance.org/ViewArticle.aspx?Articleld $=20225$

4. Nguyen E, Bouyssou A, Lassau F, Basselier B, Sednaoui $P$, Gallay A, et al. Progression importante des infections à gonocoques en France: données des réseaux Rénago et RésIST au 31 décembre 2009. [Significant increase of Neisseria gonorrhoeae infections in France: data from the RENAGO and RESIST networks as of 31 December 2009]. Bull Epidemiol Hebdom. 2011:26-8. French. Available from: http://opac.invs. sante.fr/doc_num.php?explnum_id $=7148$

5. Savage EJ, Marsh K, Duffell S, Ison CA, Zaman A, Hughes G. Rapid increase in gonorrhoea and syphilis diagnoses in England in 2011. Euro Surveill. 2012;17(29):pii=20224. Available from: http://www.eurosurveillance.org/ViewArticle. aspx?Articleld=20224 PMid:22835469

6. Bouyssou A, Janier M, Dupin N, Alcaraz I, Vernay-Vaisse C, Basselier B, et al. La syphilis en France: analyse des données de surveillance sur 10 ans, 2000-2009. [Syphilis in France: Analysis of ten years surveillance data, 2000-2009]. Bull Epidemiol Hebd 2011;26-8. French. Available from: http://opac. invs.sante.fr/doc_num.php?explnum_id $=7146$

7. Bremer V, Marcus U, Hamouda O. Syphilis on the rise again in Germany--results from surveillance data for 2011. Euro. Surveill. 2012;17(29):pii=20222. Available from: http://www. eurosurveillance.org/ViewArticle.aspx?Articleld =20222

8. Cazein F, Le Strat Y, Le Vu S, Pillonel J, Lot F, Couturier S, et al. Dépistage de l'infection par le VIH en France, 2003-2011. [HIV testing in France, 2003-2011]. Bull Epidemiol Hebd. 2011;(46-47):529-32. French. Available from: http://www. invs.sante.fr/content/download/51642/218195/version/7/file/ BEH_46_47_2012.pdf

9. Le Vu S, Velter A, Meyer L, Peytavin G, Guinard J, Pillonel J, et al. Biomarker-based HIV incidence in a community sample of men who have sex with men in Paris, France. PLoS One 2012;7(6):e39872. http://dx.doi.org/10.1371/journal. pone.0039872 PMid:22768150 PMCid:3387238

10. Stall R, Duran L, Wisniewski SR, Friedman MS, Marshal MP, McFarland W,et al. Running in place: implications of HIV incidence estimates among urban men who have sex with men in the United States and other industrialized countries. AIDS Behav. 2009;13(4):615-29. http://dx.doi.org/10.1007/s10461008-9509-7 PMid:19205867 